\title{
Historians should not only Bend over Old Books: an Interview with Professor Georg G. Iggers \\ Los historiadores no deberían inclinarse sólo sobre viejos libros. Entrevista con el profesor Georg G. Iggers
}

\author{
Yongmei Gong \\ Center for Marxist and Contemporary Development \\ East China Normal University (Shanghai). China \\ gymvic@yahoo.com.cn
}

\begin{abstract}
In this interview, Professor Georg G. Iggers, one of the foremost international experts in the specialty of the history of historiography, provides an overview of his career and ideas. He talks about his youth when he had to flee Nazi Germany with his parents; his Jewish identity; the early years of his education and university studies in the US; his interest in the Saint-Simonians and his initial contacts with European intellectual history; his involvement in the movement against the Vietnam War; his philosophical training and interests; his conversations with post-modern authors; and his interest in a "global" history of historiography.
\end{abstract}

\section{Key Words}

Judaism, history of ideas, civil rights, global history of historiography.

\section{Resumen}

En esta entrevista, el profesor Georg G. Iggers, uno de los principales expertos internacionales de la especialidad de la historia de la historiografía, hace un repaso por su carrera e ideas. Habla de su juventud, cuando tuvo que huir de la Alemania nazi con sus padres, de su identidad judía, de los primeros pasos de su educación y de sus estudios universitarios en los Estados Unidos, su interés por los saint-simonianos y sus primeros contactos con la historia intelectual europea, su compromiso con el movimiento contra la guerra de Vietnam, su formación e intereses filosóficos, sus diálogos con los autores postmodernistas, y su interés hacia la historia "global” de la historiografía.

\section{Palabras clave}

Judaísmo, historia de las ideas, derechos civiles, historia global de la historiografía.

\section{Editorial note}

In 2008 Professor Yongmei Gong, from the East China Normal University in Shanghai, interviewed Professor Georg. G. Iggers, giving him the opportunity to talk about many aspects of his intellectual and personal life. The interview, which was conducted by e-mail, was entitled "Historians should not only bend over old books: An interview with the 
famous historian Georg Iggers”. The language in which the interview was formally conducted was English, but the article was intended for Chinese readers and Professor Yongmei Gong translated it into her own language for the Chinese journal Historian's Teahouse, to be published in Issue 15, 1 (2009), pp. 7-19. Now, thanks to the kind permission of the authors to publish it in Historiografías, this will be the first time the article will appear in English. In the present text, apart from clarifying some symbols and a couple of books, the editors have only made one slight change in the subtitle, which becomes “An interview with Professor Georg G. Iggers”.

The interview contains valuable information on the life and career of this well-known and much honored historian, an outstanding expert in historiography, the author of studies on German, Western, and ultimately global historiography, and Professor Emeritus of the State University of New York at Buffalo (USA). Certainly, it will help the reader better understand the main aspects of Professor Iggers's approach to tackling the history of historiography and this is not the first time Historiografías pays attention to his life and work. ${ }^{1}$ Moreover, the journal is pleased to have him as a member of its advisory board. But with this interview Historiografías also pursues the objective of making contact with Chinese historiography, and to this end, there is nobody better than Professor Iggers. He has strengthened interesting bonds with Chinese historians with the passing of time, from the 1980s onwards, and together with some of these historians has even published some of his most recent interesting books (though - as the reader of this interview will see - this has not prevented him from criticizing crucial aspects of the Chinese political régime).

It seems obvious that, in the next decade, Chinese historiography will multiply its links with Western historiographies and the decision to hold the 22nd International Congress of Historical Sciences in 2015 in Jinan (China) will surely help. Iggers's interviewer, Professor Yongmei Gong, belongs to generations of Chinese historians that appear hugely interested in establishing contacts with Western historiography and culture, and may represent the challenge mentioned above. Yongmei Gong herself has solid international experience in cultural contacts, and she is an expert on international topics such as that of the past and present of sinology, as can be seen from her profile (below). The editors of Historiografías hope this interview will lead to greater appreciation of the modern "classics" of the history of historiography, and give an idea of how an emerging historiography like that of China is also aware of how they should be valued.

1) As a worldwide influential scholar, your Jewish identity seems to have a very important effect on your life, because your family fled Germany in October 1938 and went to the United States as refugees. And for the first time in 1942, when you were already in the US, you read about the report on the Holocaust. Even if you were not a victim of the Holocaust, does the Holocaust really strike you as an important event which led you to become a historian that takes human history really seriously and

\footnotetext{
${ }^{1}$ See Gonzalo Pasamar, "Leopold von Ranke, The Theory and Practice of History" London, New York: Routledge. 2011. Edition and Introduction by Georg G. Iggers. lii + 158 pp, Historiografías, 2 (JulyDecember 2011): pp. 116-122, http://www.unizar.es/historiografias/historiografias/numeros/2/2.pdf
} 
thinks it should not be erased from the human memory? What are the initial reasons that led you to decide to become a historian? As I know, you are from a business family. Why did you have a special interest in history and historiography?

Georg G. Iggers: This in fact is not one question but several different questions all at the same time - my identity, my relationship with the Holocaust, and finally how I became a historian.

With respect to the first part of the question, I have always felt myself to be a Jew in a cultural and religious sense, but my identity as a Jew was only a part of my total being. My Jewish identity has not been central to my scholarly work and it was shaped not by the Holocaust, which my wife and I both barely escaped, but earlier, by my experiences as a Jewish child growing up in Nazi Germany in the years from 1933 to 1938. I was born into a Jewish home and my awareness that I was Jewish was strengthened by the discrimination I experienced in Nazi Germany. Of course, the Holocaust deeply shook me. I could not imagine how Germans whom I had known as decent people could stand by and let such a thing happen.

I had already developed a strong sense of justice and a commitment to opposing injustice very early on. I was deeply upset by the Italian invasion of Ethiopia in 1935 and spoke out against it in my German public school. I was deeply shaken by the enormity of the Holocaust, also how the rest of the world looked on and let it happen as it later looked on at the genocide in Rwanda and now in Dafur. Recently in Shanghai, in response to my question, Hayden White told me that we must free ourselves of the burden of the past and live in the present. Of course, we must live in the present, but our memory of the past, with all its terrible aspects, is important in shaping our present. I have been able to return to Germany because Germans of the past two generations (much less so the generation of the perpetrators) have been willing to confront their past honestly.

As to my Judaism, I have long since abandoned the orthodoxy of my early years, but now I consider myself, as far as religion is concerned, to be a liberal Jew who maintains much of what I consider positive in the Jewish heritage, including its sense of justice, but I have freed myself from most of its ritualistic restrictions. I attend liberal religious services in which men and women are fully equal and the traditional Hebrew prayers are not totally forsaken but made more understandable in the vernacular language.

More on my identity: to a much larger extent than being a Jew, I have a European, or to be more exact, a Central European identity, an affinity with the culture of the German language world, to which Jews in the past two centuries have contributed significantly. I have a very personal identity. Throughout my life I have appreciated German culture but have seen its dangerous limitations. Today I can more easily identify with present-day Germany, which has shed its antidemocratic and militaristic traditions after the terrible things that happened. It is a new democratic Germany, a much better but by no means perfect society. Thus, I have accepted the restoration of my German citizenship of which I had been deprived by the Nazis. I also have an American identity. Coming to America from Germany in 1938 felt like suddenly catching a breath of fresh air. I very much appreciated the greater openness in contrast to Germany - its democracy. At the same time I was 
quickly aware of the other side of American society, particularly its racism, later in the McCarthy period its illiberalism, and its attempt in recent years to dominate the world. As to my Jewish identity, I feel like a Jew but not in a national sense - I am therefore no longer a Zionist and believe that Jews should continue to make a contribution to culture in the Diaspora. My Judaism had not directly affected my work as a historian. My identification with my Judaism, with Germany, and with America is a critical one, recognizing both the positive and negative sides of each one. My identity thus goes beyond national and religious boundaries; perhaps to call myself a citizen of the world may be going too far, but I have always had affinities with other cultures and have good friends in Asia, India and Africa.

Now how do I explain how, coming from a business family, I became an academic? I was very deeply influenced while a child in Germany by the spirit of the youth movement. Part of this was a reaction against the bourgeois character of our parents. There was a lot of romanticism in this reaction, in the case of the Jewish youth movement which I joined, a determination to leave our parents' world of offices and commerce. For us the ideal society was the agricultural, communitarian kibbutz, which in the long run proved to be an illusion, even ultimately a dangerous one. In questions 2 and 3 I shall explain how I ultimately became a historian.

2) At high school, you had huge interest in international languages, such as French, Spanish, Italian, Latin, Hebrew, Esperanto, and even Chinese. I find this really impressive. Can you say something about language teaching in the 1940s in the USA and do you think you have benefitted a lot from this education?

Georg G. Iggers: From very early in my youth I was already opposed to every form of nationalism. In 1940, when I was thirteen, I joined and became an active member of the Union Now movement - later known as the World Federalists, who called for a worldwide federation of democratic states after the end of the war. This led to my interest in international languages such as Esperanto, which could contribute to international communication. I began to work on an international language which would be simpler in its vocabulary and grammatical structure than Esperanto or any of the artificial international languages. Ultimately none of them succeeded, and neither did mine have any chance as English became the world language. I began to dabble in a large number of languages: the Romance languages, Russian, classical Latin and Greek, and as you said, even Chinese, although I made little progress. I had learned Hebrew, again not very well, as part of my religious education. Language education was not well developed in schools in the US at the time. I took French and Spanish at high school, but apart from that, I taught myself.

3) You were an activist in the YMCA [Young Men's Christian Association] in 1943 when you were a college student at the University of Richmond. You had a double major in French and Spanish, but also took a number of philosophy courses. You only spent two years finishing your B. A. [Bachelor of Arts] (as a 17-year-old). And then began your graduate studies at the University of Chicago. At the time, you thought this university more closely resembled the German university system because it gave students more freedom. You mentioned in your biography that this was naive and uninformed. At the University of Chicago you were accepted by the German 
department. You found your real interest was in the history of ideas. There you wrote a Master of Arts essay entitled "Heinrich Heine and the Saint-Simonians". The interest in the Saint-Simonians seems a decisive turn in your academic career, and meanwhile you were active in social and political involvements. It is very interesting that you were even told by Professor Hans Rothfels that "you have no understanding of history and should not pursue a doctorate". From all this information about your earlier life I understand there is a political stand in your thought. What is it? Is it related to your history studies? How? What did you think about the Saint-Simonians at that time? Have you changed your ideas about them since then?

Georg G. Iggers: Again this question is actually a compound of a number of very different questions.

First with regard to my activism in the YMCA in 1943: I was not active in the YMCA but very active in an interracial student organization founded by the YWCA [Young Women's Christian Association]. First of all the background: I came to New York with my parents in October 1938 and for the first three months was indoctrinated in American democracy. In January 1939 a Jewish aid organization resettled us in Richmond, Virginia, where they found a job, albeit poorly paid, for my father, and housing for us since the job situation in New York City was well nigh impossible. Richmond had been the capital of the Confederacy during the American Civil War from 1861 to 1865 and there were still reminders everywhere of the Confederate past. I was shocked by the racial segregation I found upon our arrival. In Richmond all facilities were segregated, including the schools I attended. The University of Richmond, at the time a very conservative school affiliated with the very conservative and racist Southern Baptist Association, was the only college since I lived in Richmond that I could attend. The YWCA organized an interracial group of white and black students, the Richmond Intercollegiate Council, which met monthly in town - we could not meet on the University of Richmond campus - with about three hundred students, black and white, facing a new experience. I was very active in recruiting students.

In the summer of 1944, I went to the University of Chicago to begin my graduate work. I had intended to study linguistics, but linguistics as taught there was something very different from what I had expected, not a historically oriented comparative study of languages but an analytical approach to linguistics, which was of little use for my international language project. I therefore went into the German department. I became aware of the futility of my project and turned increasingly to the comparative history of ideas. My favorite German poet had been Heinrich Heine, a liberal, incidentally of Jewish origin, who left Germany in 1831 for life-long exile in France. In 1844 he got to meet the young Karl Marx who had just fled from Germany to Paris with his wife, Jenny, and their small child. Heine and Marx became good friends and Marx assisted Heine on his major poem, "Germany, A Winter Tale", a satirical critique of German politics and nationalism. I never got to Marx in my thesis but instead dealt with Heine's association, soon after his arrival in Paris in 1831, with the French socialist group the Saint-Simonians.

My own sympathies were with a democratic form of socialism but I soon discovered how authoritarian the socialism of the Saint-Simonians actually was. After receiving my 
Master of Arts, in 1945, I spent a year at the New School for Social Research in New York City where many German, Austrian, and Italian refugee scholars taught and where I studied sociology and philosophy, while working in a garment factory to support myself. In the fall of 1946 I returned to Chicago and entered the interdisciplinary Committee on the History of Culture, where I concentrated on European intellectual history in the first half of the nineteenth century with fields in the political history of France and Germany, philosophy, literature, and religion. I decided to write my dissertation on the political philosophy of the Saint-Simonians, not because I sympathized with them but because I was critical of them. They saw modern civilization in a deep crisis and wanted to restore order and authority, turning away from the Enlightenment to Catholic counter-revolutionary thought adapted to socialist theory. The Saint-Simonians did not mark a turning point in my academic career, but they led me to an interest in the philosophy of history. Hans Rothfels played a very marginal role in my studies. I took two seminars on nineteenth-century German history with him. I disagreed with him vocally on his ultra-nationalistic, anti-democratic outlook and wondered why he had left Nazi Germany. In fact he had cooperated very closely with the Nazis until he was finally forced to leave due - although I did not know at the time and he did not reveal to his Jewish origins.

4) I am very much impressed by your political involvement, such as the Little Rock case, the Civil Rights Movement in the South, the opposition to the Vietnam War in Chicago, and so on. In these battles you were always together with Wilma. You fight for equality and freedom. Do you think you have the responsibility to change the world as historians? What are your ideas about values and ethics? Do you agree that history studies should only deal with the documents and keep away from the politics so that they can remain unprejudiced, as some scholars think? How do the interpersonal contacts and involvement in social issues relate to your scholarly activities?

Georg G. Iggers: This is again a complex question. Wilma and I have been together since we met at the University of Chicago over sixty years ago. Although we are in some ways very different people in terms of temperament and to an extent in our intellectual interests, we have largely agreed on social issues and worked together. We married in 1948 and in 1950 accepted positions at a black college in Little Rock, Arkansas, where we also lived in the black community. Little Rock was no longer the Old South, but there was the beginning of a consciousness that things should change. Shortly after we arrived, I succeeded in having my black students admitted to the white public library. Thereupon the Little Rock chapter of the most important civil rights organization, the National Association for the Advancement of Colored People (NAACP), asked me to become chair of their education committee in which capacity I handled the research and planning that ultimately led to the suit which resulted in the beginning of desegregation of the white public high school. Wilma assisted me at every step along the way. Although there were considerable racial tensions in this Southern city, we were never isolated from whites who shared our views. We thus lived in an interracial setting.

As to your question about my idea of values and ethics, it is clear from the above that I, and also Wilma, firmly believe that there are values of human dignity and freedom which are valid for all societies. This not only meant engagement in civil rights, but also led to our 
opposition to militarism and war. Hence, our involvement in the movement against the Vietnam War. We did not believe in violent confrontation, but in peaceful alternatives. During the war I counseled hundreds of war resisters. I always felt an ethical commitment in my scholarly work. The idea that the historian should just stick to the documents and avoid making political stands overlooks the fact that all historical writing rests on value assumptions, which the historian may not admit but which nevertheless shape his historical outlook and color his writing. History, of course, requires serious research and honesty. The reality that all historians are guided by philosophical and ethical assumptions does not mean that they may dispense with historical truth. Historians in the past have too often served to help buttress historical myths, and history has been used in authoritarian states in support of ideologies with little basis in reality. History can be committed and yet honest; history must not become a tool of propaganda. As for interpersonal contacts they have been very important for me and my scholarship beyond national and ideological boundaries.

5) In your academic career, who were the scholars that most influenced you? People like Max Weber, Ernst Troeltsch? And how? How did you absorb ideas and approaches from these sociologists or others?

Georg G. Iggers: This question is difficult to answer. There was no one particular scholar. I read a lot of sociology and philosophy and learned a lot, but no one thinker completely reflected my position although they helped me develop intellectually. I don't consider any of them to be the final word. I have not only read Weber and Troeltsch but treated them at length in my The German Conception of History from a critical perspective. Weber made an important contribution in his attempt to bridge the logic of the natural sciences with that of the human sciences. The scholar to whom I feel most indebted personally is my teacher James Luther Adams, a theologian, deeply steeped in German intellectual currents in the early twentieth century, Max Weber and Ernst Troeltsch, and Paul Tillich. I dedicated The German Conception of History to him rather than to the director of my dissertation, Louis Gottschalk, because Adams most closely corresponded to my model of a scholar with an active social conscience while Gottschalk, from whom I learned a lot about the French Enlightenment, warned me that I should stick to my scholarly work lest my social activism should damage my career, as it probably did.

6) In 1962 you wrote an article comparing how differently Leopold von Ranke was understood in Germany and America in the nineteenth century. Could you please make some general points about this different view?

Georg G. Iggers: I have dealt more extensively with this question in the draft of a chapter I have just completed on "The Intellectual Foundations of Nineteenth-Century Professional Scholarship” to appear in Daniel Woolf, (ed.), Oxford History of Historical Writing. ${ }^{2}$ In America Ranke was understood to be the father of scientific history, essentially a positivist, who was committed to thinking that on the critical examinations of the documents he could write a history as "it actually happened", free of any philosophic

\footnotetext{
${ }^{2}$ The text was finally published under the title of "The Intellectual Foundations of Nineteenth-Century 'Scientific’ History: the German Model”, in Stuart Macintyre, Juan Maiguashca, Attila Pók (eds.), The Oxford History of Historical Writing. Vol. 4 (Oxford University Press. 2011).
} 
presuppositions or moral judgments. It misunderstood the intellectual context in which Ranke wrote, his roots in German Idealism, which shaped his history and went beyond the factualism for which the American historians honored him in 1885 shortly before his death, with the first honorary membership in the newly formed American Historical Association.

7) Is it possible that historians can establish an empirical social or historical science with limited hypotheses and theories? What is your opinion of Karl Popper?

Georg G. Iggers: Yes, as long as it recognizes its limits. Karl Popper has recognized this, but also warned against easy conclusions, stressing that all propositions for scientific validity must be formulated in such a way that they can be falsified. The problems with the covering law as formulated by Popper and Hempel is that it cannot easily be applied to intentions and volitions which shape human history and which cannot be understood in the causal terms set by the covering law. On another aspect of his thought, Popper is right in warning against speculative philosophies of history and the political aims which these philosophies serve, but not in his outright rejection of all state intervention or planning.

8) As I know, your research on historiography constitutes a comparative and international approach, and you have finished a book about global historiography together with Edward Qing Jia Wang. Can you tell me something about this book? ${ }^{3}$ And do you think it is possible to have an integrated global history and historiography?

Georg G. Iggers: We have tried to deal with the interaction of Western and nonWestern historical thought and historiography since the late eighteenth century at the point when Western imperialism and colonialism made themselves felt. We have been interested both in the impact of Westernization and of the resistance to it and the existence and strengths of non-Western historiographical traditions. Is an integrated global history of historiography possible? A global history of historiography, yes; an integrated one, much less so.

9) You have talked about Marxist historical theory and its importance for the writing of history. Can you explain your ideas about it? Do you treat Marxism as an important intellectual tradition which is still alive and useful in contemporary society?

Georg G. Iggers: I am not a Marxist but I consider Marx the most important single thinker of the nineteenth century. He made a tremendous contribution to the formation of an analytical social science. I consider Capital (Das Kapital) vol. 1 significant for two reasons. One is his analysis of capitalism, doing something which Max Weber did later, working out an ideal type of capitalism and how it functions. The second is the critical note: what he calls the critique of political economy, pointing not only to the economic dysfunctions of capitalism but also its human costs, the fetishism of commodities with its sacrifice of human values to a system condemned to the maximization of profits. But I also see his limits. From the perspective of the present, much of what he foresaw has developed

\footnotetext{
${ }^{3}$ Georg G. Iggers, Edward Qing Jia Wang, A Global History of Modern Historiography (Harlow, England, New York: Pearson Longman, 2008) (with the assistance of Supriya Mukherjee).
} 
differently. He was right in seeing the trend to the world concentration of capital but saw this trend in too simple forms. He pointed rightly to the social influence of material forces but in seeing these as determining what he called the intellectual and cultural superstructure overlooked the intellectual, cultural, and religious factors, among others, that influenced historical development. Thus, he was unable to analyze the destructive force of nationalism. And these limits apply not only to the understanding of the present world but also to his understanding of the time in which he lived, which could not be understood in terms of his base/superstructure theme. Thus, even the nineteenth century developed differently from what he predicted; the communist revolution he and Friedrich Engels expected took place in no developed country, either then or later. And the world has developed differently than it was supposed to according to his overly optimistic philosophy of history leading to human emancipation and an end to conflict. Nevertheless, I consider Marxism an important intellectual tradition that is still alive and useful in contemporary society. His vision of progress is dead and his concept of class is too simple to explain the complex composition of society. But against the advocates of modernization, who see in highly developed capitalism the high point and end of history, Marxist thinkers have rightly pointed at the exploitative character of capitalism, today on a global scale. Especially in the former colonial world Marxism has been a source of light for the critique not only of capitalism but also of its effect on the world it has created. While Marxism in the dogmatic form of Marx and Engels belongs to the past, the core of its critique of capitalism and the emphasis to the power it asserts on all aspects of life, the fact that it cannot exist without exploitation, is still valid and is still accepted by many voices that no longer call themselves Marxist but continue Marxist commitments under modern conditions.

10) I notice that you always believe in the Enlightenment ideas of human dignity and self-determination. However, some philosophers and historians blame Enlightenment ideas for the wars and intensive struggles between human and nature, and so on. How do you defend your belief in the ideas of the Enlightenment?

Georg G. Iggers: For over a century the Enlightenment was under attack by thinkers from the ultra-right such as Friedrich Nietzsche and Martin Heidegger, but later also by thinkers who claimed to be left-wing, such as Max Horkheimer, Theodor Adorno, and Michel Foucault. In 1944, Horkheimer and Adorno in Dialectic of Enlightenment, written in exile from Nazi Germany, held the Enlightenment responsible for the totalitarian regimes of the twentieth century and particularly for the Holocaust. They saw the core of the Enlightenment in the attempt to reduce everything to instrumental reason in order to establish control over all aspects of society. They argued that, by wishing to banish all myths and replace them with science, the Enlightenment had in fact created a new myth: that of science.

To see Nazism as a product of the Enlightenment is nonsense. Ideologically, Nazism was a reaction against Enlightenment values and modernity, although the Nazis utilized modern technology in pursuit of their vicious aims. Rational organization can, of course, be used to establish domination over human populations. But the critics of the Enlightenment have willfully ignored its normative side, its very commitment to human dignity. The great advances which have been made in the emancipation of men and women from domination and subordination and in the achievement of political democracy and social equality are 
unimaginable without the credo of the Enlightenment. Post-colonial thinkers like Ashis Nandy in India have joined the attack on the Enlightenment and on the Western scientific heritage, which they condemned as instruments of colonial domination and exploitation, without acknowledging that without the enlightened outlook India would have been unable to create a modern society. Nandy called for a return to pre-modern mythical thinking, abandoning the secularism of the Enlightenment and Western civilization, which he blamed for the horrors of the modern world. But as his Indian colleague Sumit Sarkar warned, the whole progress of India towards liberation and to freeing women and the subaltern classes from their subordination rested on the concepts of the European Enlightenment of the rights of men and women. This is also my position. I recognized that the Enlightenment is doubleedged as is the process of modernization, but I believe that its values are central to achieving a civil, that is, a civilized society.

11) Postmodernism states that history is a form of literature - that it is in no way a scientific enterprise. There is no historical truth but fiction. Some Chinese historians do not agree with postmodernism, but their position is that it is the literature narrative tradition in Western historical writings which, for lack of enough accurate historical records, result in the postmodernist statements. Do you think history is a scientific enterprise? Is there any historical truth? Can historians reach the truth? Both postmodernism and you disagree with Ranke, so what are the differences between postmodernists and you on Ranke?

Georg G. Iggers: I have for many years exchanged ideas with Hayden White, who has been a main advocate of a postmodern conception of historiography. Postmodernism states that history is a form of literature and that it is in no way a scientific enterprise. There is no historical truth but only fiction. This is an extreme formulation, against which I have argued. What is meant by scientific enterprise? If it means a causal science like natural science, it is, of course, not a science. If it means research-oriented inquiry following established methodological guidelines, it has characteristics of a science. I agree with Hayden White and the postmodernists that every historical account is largely narrative, but not that history is merely a form of imaginative, that is fictional literature, the statements of which cannot be validated. Truth is, of course, an elusive term. I believe that there is a past historical reality, of men and women who actually lived, but also that the reconstruction of this past is never perfect but always reflects the subjectivity of the historians and the questions they ask. The differences between Ranke and me are apparent from what I just wrote. For Ranke, objective knowledge of the past was possible, for the postmodernists it is not. My position is between the two.

12) In 1968 you published one of your most important books The German Conception of History. The National Tradition of Historical Thought from Herder to the Present. Can you say why you wrote on this topic and how you put this book together? Is it true, as some reviews stated, that you were trying to seek the nationalist ideology that was responsible for many Germans accepting Nazism?

Georg G. Iggers: This was a critique of the German historical profession over a century and a half and its role in helping to fashion a sense of national identity which, while 
it did not directly pave the way for Nazism, made it easier for German historians to accommodate it and, in some cases, to support it directly.

Modern professional historical studies originated in the nineteenth century at the universities in Protestant Germany. The historians claimed that they had elevated history to a science, albeit a humanistic one, committed to objectivity and free of bias. The German model was largely accepted as historical institutions internationally were professionalized following the German model. I sought to disprove the assertion of the German profession that it represented impartial, scientific historiography and to demonstrate its involvement in a national, or rather nationalistic, ideology which sought to differentiate Germany's way to modernity with its semi-autocratic institutions and values from Western democracies. The book was closely linked to my biography and conceived as a critique of an illiberal German tradition with the aim of furthering a democratic culture in Germany. It was also a critique of German historicism which denied that there are universal standards of human rights by which historical institutions and political practices could be judged. In America the book was seen primarily as an academic work. It was almost immediately translated into German, where it had a much wider circulation, and its political character was understood by a new generation which began to reassess the German national tradition of historical thought critically.

13) In 1997 you published Historiography in the Twentieth Century, in which you explored the history of historiography in the approach of societal history. Could you please talk about the new currents in contemporary Western historiography?

Georg G. Iggers: There was a second English edition in 2005 and a second German edition in 2007, both of which sought to bring the book up to date. The earlier edition had dealt critically with postmodernism, culturalism, and the linguistic turn, which had challenged social scientific approaches to history and proceeded from literary perspectives. In my eyes the great contribution which came from this literature was the widening of the scope of topics dealt with by history, women, ethnic minorities, marginal groups, and the broad portions of the population which had been neglected previously. On the other hand, by equating history and literature, postmodernism, culturalism, and the linguistic turn hurt the attempts at serious historical studies.

The world changed quite markedly after the end of the Cold War. Under the impact of globalization, historical studies have increased their global character, without excluding the new topics introduced by postmodernism, but returning to stricter methodologies dealing with the global world, both with globalization and with resistance to it.

14) When there were still Cold War confrontations in the 1980s, you were very active in organizing an international commission on the history of historiography, and had discussions with historians from the West and the East, including those from China. It is an attempt to cross the ideological divides. According to your experience, is it possible to go beyond the ideological and cultural divisions? How can we make this possible? 
Georg G. Iggers: As someone who believed in peace and international understanding, I saw both sides of the Cold War critically and sought to build bridges. In 1961, I returned with Wilma and our three children to West Germany. In 1966, I began going to East Germany as well, and although I was not a Communist, I was able to establish channels of communication. I also went with Wilma to Czechoslovakia the same year, and very soon after that to Poland and Hungary. In 1980, at the founding of the International Historiographical Commission, I saw to it that both East and West were represented. I invited Professor Zhang Zhilian to visit my historiographical seminar, which he did. Shortly thereafter, in 1982, Professor Qi Shirong of Beijing Teachers College (now Capital Normal University) joined us in Buffalo for half a year. We had already begun a student exchange. In the summer of 1984, Wilma and I came to China for six and a half weeks on the invitation of Professor Qi. Contacts with the Soviet Union were less successful, but we had a young Soviet historian as a visiting professor in the 1984-85 academic year in my department. At the same time our exchanges with East Germany became more intensive. I arranged for East German historians to come each year to the German Studies Association in the United States where they met with West German and American historians. Every time they also met at my university in Buffalo. Soon we also arranged an exchange of Buffalo graduate students and doctoral candidates from the Academy of Sciences of the GDR.

15) As a historian, what is your hope for the world in the Twentieth-first century? As an old friend, what do you want to say about how we can improve historiography in China? Please express your wishes to Chinese scholars, especially for the younger generation.

Georg G. Iggers: My hope is very simple: for a saner and more humane world, where tyranny, war, and poverty are overcome and humans everywhere live in dignity. But unfortunately this is a utopia. My expectations after what we have already experienced in this century are therefore very pessimistic. But I do not think that we should be passive in the present situation.

What do I want to say to our Chinese friends? On the positive side, I have been impressed again in my recent visits to China by the openness of discussions in Shanghai, Nanjing, and Beijing, free of all dogmatism. I am also impressed by the extent to which Chinese historians have joined international discussions. All these reflect a great degree of freedom of expression and the ability of Chinese scholars to critically address themes which could not be addressed earlier. On the negative side, I am also aware of the limits of free expression and the remnants of dogmatism. I am frankly deeply disturbed by the continued incarceration of dissidents. China still has a way to go before historians can express themselves free of the fear of state intervention. As for the younger scholars, I urge them to have a global perspective, to be aware of current historical studies both in and outside China, and to participate, learn from, and contribute to international debate.

16) All through your life you have obtained numerous awards including the Order of Merit (First Class) of the Federal Republic of Germany in 2007. Your accomplishments as a historian, ethicist and social activist will continue to color 


\section{intellectual, cultural and political lives far into the Twentieth-first century. How do you see your roles as a historian, ethicist and social activist?}

Georg G. Iggers: As to my role as a historian, ethicist, and social activist, I have answered this in question 4. As for the Medal of Merit, I just want to mention two things which were stressed in the presentation: my involvement in the civil rights movement and the recognition by the Federal Republic of Germany, which pleased me especially for my efforts to build bridges between East and West Germany during the Cold War.

\section{Profile}

Professor Yongmei Gong is currently pursuing her career at the East China Normal University in Shanghai, where she received his Bachelor of Arts in 1990, and where she is at present Vice Director of the Center for Marxism and Contemporary Development. With international experience in setting up cultural contacts, she was Visiting Scholar at the Department of Philosophy at the University of Victoria (Canada) from 1997 to 1998, and Visiting Fellow at the prestigious US Harvard-Yenching Institute from 2004 to 2005. She is author of the book Philip A. Kuhn and His Chinese Historical Studies (Shanghai Lexicographical Publishing House, 2008, 352 pp.), where she examines the life and work of the modern pioneering author in sinology and Harvard Emeritus Professor, Philip A. Kuhn.

La profesora Yongmei Gong desarrolla habitualmente su carrera en la East China Normal University de Shanghai, donde obtuvo la licenciatura en 1990, y donde es en la actualidad la vice-directora del Centro para el Marxismo y el desarrollo contemporáneo. Posee una experiencia internacional en el establecimiento de contactos culturales habiendo sido investigadora visitante en el Departamento de Filosofía de la University of Victoria (Canada) en 1997-1998, y en el prestigioso Instituto Yenching de la Universidad de Harvard en el curso 2004-2005. Es autora del libro Philip A. Kuhn and His Chinese Historical Studies (Shanghai Lexicographical Publishing House, 2008, 352 pp.) donde examina la vida y obra del autor pionero de la Sinología y profesor emérito de Harvard, Philip A. Kuhn.

Fecha de recepción: 3 de febrero de 2013

Fecha de aceptación: 23 de marzo de 2013

Publicado: 15 de junio de 2013

Para citar este artículo: Gong Yongmei, "Historians should not only Bend over Old Books: an Interview with Professor Georg G. Iggers”, Historiografías, 5 (enero-junio, 2013): pp. 94-106 http://www.unizar.es/historiografias/historiografias/*

http://www.unizar.es/historiografias/historiografias/numeros/5/yongmei.pdf 